\title{
INNOVATIONS IN RURAL TOURISM IN POLAND AND ROMANIA
}

\author{
Alexandru Sin ${ }^{1}$, Czeslaw Nowak ${ }^{2}$, Malgorzata Bogusz ${ }^{3}$, Magdalena Kowalska ${ }^{4}$, \\ Emília Janigová ${ }^{5}$ \\ *Corresponding author E-mail: alxsin@gmail.com
}

\author{
A R T I C L E I N F O \\ Review Article \\ Received: 27 May 2020 \\ Accepted: 01 June 2020 \\ doi:10.5937/ekoPolj2002623S \\ UDC 001.895:338.48-41(1-22) \\ (475)(498)
}

\section{Keywords:}

innovations, travel packages, educational farms, network tourist products

JEL: Q01, Q26, Q56, Q57, O13, O35, O36

\section{A B S T R A C T}

The interest in rural tourism in Poland and Romania is the result of processes originating from economic and social factors reflecting the needs of both rural inhabitants and tourists. A significant growth in the field of rural tourism leads to implementation of innovative products in the development of tourist services. The aim of the study presented in this paper is to show the essence of innovation as a component of the contemporary tourist industry, and to present the type of innovations that occur in rural tourism in Poland and in Romania. The theoretical part analyses innovation in the field of rural tourism. The empirical part, in turn, presents case studies of tourist businesses in rural areas, taking into account the implemented innovations, in both Poland and Romania. The case studies are presented based on interviews with owners of tourist facilities.

(C) 2020 EA. All rights reserved.

1 Alexandru Sin, $\mathrm{PhD}$, Research scientist, National Institute for Economic Research "Costin C. Kirițescu” of Romanian Academy, Bucharest, Romania, alxsin@gmail.com, Mobile: + 40722391 097, ORCID: 0000-0003-1814-0602

2 Czeslaw Nowak, Prof. Dr. Hab., University of Agriculture in Krakow, Poland, Faculty of Agriculture and Economics, czeslaw.nowak@urk.edu.pl, office phone number: + 4812662 43 74, ORCID: 0000-0002-6693-4039

3 Malgorzata Bogusz, PhD,University of Agriculture in Krakow, Poland, Faculty of Agriculture and Economics, malgorzata.bogusz@urk.edu.pl, office phone number: + 4812 66243 75, ORCID: 0000-0002-0852-1148

4 Magdalena Kowalska, $\mathrm{PhD}$, University of Agriculture in Krakow, Faculty of Agriculture and Economics, magdalena.kowalska@urk.edu.pl, office phone number: +48 126624438 , ORCID: 0000-0002-2859-7676

5 Emília Janigová, PhD, University Hradec Králové, Faculty of Education Rokitanského 62, 50003 Hradec Kralove, Czechia, tel. +42 1948 901745; emilia.janigova@gmail.com, ORCID: 0000-0003-0672-1194. 


\section{Introduction}

The issue of innovation in contemporary markets mainly relates to factors such as increasing competitiveness or achieving success. The concept of innovation should be understood as "...implementation into service of new products, ideas or procedures. Therefore, it will be any positive changes implemented for use, which are seen as new from the point of view of the entity introducing them" (Panasiuk, 2014).

According to M. Idziak and W. Idziak (2015) innovations can be considered from two perspectives: business and social. The business approach divides innovations into product innovations, and means implementing either a new or significantly improved product or service, process innovations (the introduction of a new process), marketing and organizational innovations (the implementation of new marketing methods in the first case, or new organizational methods in the second $)^{6}$.

On the other hand, social innovations are primarily new ways of solving social problems and methods of social activation, as well as new models of functioning of social institutions. Moreover, the implementation of new forms of organization of free time activities, or educational and cultural activities, is also considered.

Recent years have been a time of the growing importance of innovation on the tourism market. Tourism contributes to the development of culture, tradition and beliefs of people (Durkalić, 2015). Innovation in tourism usually involves modifying already functioning tourist products and adapting them to the expectations and requirements of the buyer. Importantly, it is an activity designed to forestall competitors' actions. According to M. Wozniczko and D.Orlowski (2012) "Striving for raising innovation and competitiveness of tourist products is one of the classic premises in the process of tourism development."

According to J. Majewski (2015) the very popularity of the problems of innovation (as well as creativity) should, in the first place, be considered in two aspects. The first is in its close connection with European Commission policy, which regards innovation as one of the primary determinants of development, as well as an important condition for the allocation of funds. On the other hand, the second aspect lies in the current models of tourist consumption, in which, according to Majewski, "creativity and innovation have become simply fashionable." Importantly, while affecting the functioning of the tourism industry, both of these areas have become an essential element of the market, determining which product, and at what time, becomes innovative.

Krzyzanowska (2013) indicates the different ways of functioning of innovation in tourism. An innovative action will surely be creating a new, not-yet existing tourist product - e.g. a group of themed villages - as well as creating an institutional environment or undertaking marketing activities for existing elements of natural and

6 The authors refer to the so-called Oslo methodology, the name of which comes from the title of a handbook of international standards in research on innovations in two sectors: industry and services. 
cultural heritage. Moreover, an innovative activity may also be a tourist product in the form of a spot, e.g. an object, a trail, as well as an event, such as a cultural event or service, or an organized trip. According to Krzyzanowska, to talk about creating an innovative product in rural tourism, the common action of many private and local parties is necessary. This can be difficult, if only because of the fact that it requires an appropriate management strategy, as well as due to the necessity of incurring relatively high costs.

The entities whose activity forces innovations are not only tourist businesses, but also suppliers, competitors, employees, consulting companies and even consumers themselves (Panasiuk, 2014). However, it seems that from the point of view of the process of innovating in the tourism industry, the most important parties are the individual service contractors who, while creating their own tourist product, usually also make use of:

- Knowledge, skills and material resources associated with the interests of the owner, their passions, profession or business activity, as well as local traditions and customs;

- Owned properties;

- Finished products modelled on actions taken in other areas (Krzyzanowska, 2013)

The aim of the study presented in this paper is to show the essence of innovation as a component of the contemporary tourist industry, and to present the type of innovations that occur in rural tourism in Poland and Romania. Below, some of their many innovative actions are described, such as thematic villages, educational farms and networking of tourism products, supplemented with examples of good practice. Based on the interview questionnaire, being the research tool used for the purpose of the study, the empirical part describes the particular rural tourist facilities, taken into account the implemented product innovations. The research was conducted in 2018 in Poland and in Romania.

\section{Thematic villages}

An interesting example of innovation in rural tourism is the concept of thematic villages, the origins of which can be linked to implementation of the LEADER program. According to M. Mackowiak and P. Seelieb (2009), a thematic village is "a village in which development is subordinated to one, leading idea. The theme is based on a quality which is characteristic for the village, interesting, something of which the village is, or may become known." Thematic villages are slightly more vividly determined by W. Idziak (2008), who writes that they "created a new concept of its development, the subject for a new story, thanks to which the village community will begin to live a new life. This new story will lead to new events."

There is no one universal way to create a thematic village, because the process runs differently in places that have a clear specialization associated with crafts, agriculture or natural values, and in a different way in villages where no such thing exists. As far as 
the aim of thematic villages, it is to create new opportunities for the local community to earn money. It is not, for example, about introducing new types of farming or cultivation, but rather the use of an existing basis for the creation of original ideas, thanks to which the village can become a more attractive place - for both its inhabitants, creating new earning opportunities, and tourists (Mackowiak, Seelieb, 2009).

The psychological aspect - especially in terms of the mentality of people, therefore the tradition of their joint activities, social activity, as well as the presence of leaders - is undoubtedly important from the point of view of new initiatives in the local environment, in this case - thematic villages (Idziak, 2005)

Currently, there are still many possibilities for using innovative tourist products (as they are broadly defined) in the form of thematic villages (Idziak, Idziak, 2015). The use of "symbolic and metaphoric values" is mainly indicated as a subject of specialization, as well as wide implementation of information technologies in the product, as well as in its logistics and management. New opportunities are also created by a modern approach to educational activities in thematic villages, including innovation in the range of forms and methods of education outside school. It is also worth noting the introduction of social innovations in the specialization of the village, related to the problem of social exclusion. Many examples indicate that the activities directly related to thematisation, and consequently to the creation of thematic villages, have a direct impact on the emergence of social inclusion processes in their local environment (Idziak, Idziak, 2015).

\section{Educational farms}

Educational farms (or educational enclosures) are an example of the functioning of innovative forms of entrepreneurship in rural areas in Poland. This concept encloses "agricultural farms holding livestock or crops intended for presentation to groups of children and adolescents invited within the framework of school programs, or opened as tourist attractions for families with children and adults travelling alone" (Bogusz, Kmita-Dziasek, 2015). One requirement to meet here is the realization of an educational program, the topics of which include several areas: crop and livestock production, processing of agricultural crops, ecological and consumer education, cultural heritage, traditional crafts and folk art.

Educational farms are part of the National Network of Educational Farms, in which membership is voluntary and takes place at the request of the farm owner and on the recommendation of an advisor from the agricultural consulting centre appropriate to the given voivodeship. Joining the network brings with it certain benefits, defined in the Network Regulations. These include:

- " the right to identify the educational offer with the logo of the Network;

- $\quad$ promotion of offers in the national Internet system;

- promotion at fairs and other promotional events and in media; 
- access to substantive guides;

- participation in periodic training and advisory support;

- exchange of experiences on a social network website" (Kmita-Dziasek, 2015).

One of the assumptions upon which the activity of the National Network of Educational Farms is based lies in the dissemination of knowledge, both about the origin of food and the importance of agriculture. This is why a large part of the educational program offered by such farms is taken up by issues of environmental and consumer awareness, e.g. traditional food-making, processing, local and regional cuisine and customs associated with the preparation of dishes. Some of the farms belong to the Regional Networks of Culinary Heritage, within the European Network of Regional Culinary Heritage, while others carry out educational activities using products from the national List of Traditional Products for organic farming (Kielian, 2015).

It is worth noting that the interest in conducting educational activities as an additional activity largely applies to owners of agritourism farms. This is undoubtedly closely related to the specific nature of this type of entity. What's more, increased interest in recreation in the countryside also brings an increase in expectations about what's on offer, while agritourism ceases to be exclusively connected with a stay at a farm and the possibility of purchasing food from it (Kmita-Dziasek, 2015).

\section{Network tourist products}

Networking of tourist products is definitely an activity of an innovative character. The starting point for building a network in rural areas should be the belief that the inhabitants of a given region can benefit from the development of a network of rural tourist sites (Vinohradnik, Bogusz, 2011). A network tourist product, according to the definition approved by the Polish Tourist Organization (POT), is a "readyto-sell, packaged and commercialised offer, based on a distributed structure of entities, attractions, destinations, service points and objects functioning as a single coherent concept, which has a joint, leading characteristic (brand)" (Kachniewska, 2015). With regard to the tourism industry in rural areas, the Agricultural Advisory Centre branch in Krakow defines a network product of rural tourism as an "offer ready to sell in rural areas, presented in tourist packages tailored to specific groups of recipients, based on a distributed structure of entities, attractions, destinations, service spots and objects, which function as a single coherent concept satisfying the needs of tourists and providing a guarantee of quality and uniqueness" (Vinohradnik, Bogusz, 2011). K. Vinohradnik and M. Bogusz (2011) point to the fact that the process of building a network of tourist products consists of four basic elements: an analysis of the attractiveness of a given area; the selection of an initial variant of the tourist product; determination of tourists' preferences and current trends in national and international tourism, and definition of the final variants of a tourist product, including the construction of their implementation program. 
The Polish Tourist Organization emphasises several important features of a network tourist product, namely:

- Dispersed structure of the entities, both from the public and private sectors, as well as the social sector,

- The multiplicity and diversity of services, elements of infrastructure and tourist assets,

- Common (uniform) concept of functioning,

- Cooperation and agreement between partners,

- The existence of a "product leader",

- Product name - branding,

- Blurring of the administrative and geographical boundaries (Kachniewska, 2015).

The networking ultimately leads to creation of a brand, and a network product of rural tourism. According to A. Sieczko (2011), thanks to the brand the product begins to stand out from other products, since it is "unique, original and not anonymous." Additionally, it allows for identification of a given region and seller, as well as becoming an important element of communication between providers and consumers of tourist services. K. Vonohradnik and M. Bogusz (2011) define the brand as "the wholeness composed of the product, its artistic visualization, the identity and image of the manufacturer along with the emotions associated with the product or the manufacturer, certain characteristic and values." Referring the brand to the network product, the authors claim that networking should be considered a feature that distinguishes a specific tourist product as coming from a specific area.

\section{Case studies from Poland and from Romania}

\section{Networking for development - The Transylvanian Highlands}

The Transylvanian Highlands is an initiative formed in 2015 by 13 organizations: NGOs and Local Action Groups, including local administration bodies.

Their objective is to promote the natural and cultural heritage by developing an ecotourism destination within a Natura 2000 protected area, specifically the area called Podișul Hârtibaciului - Târnava Mare - Olt, placed in Transylvania region, between the cities of Mediaș, Sibiu, Făgăraș, Rupea and Sighișoara. This also contributes to the objective of increasing the sustainably managed forest areas, identified as a sensitive issue within Nature 2000 network in Romania (Niculae et. all, 2017).

Transylvanian Highlands acts as a facilitator for local networking, providing examples for best practices, animating working groups and promoting cooperation between all interested private organizations, but also between private and public bodies.

Their activities are addressed to a large range of stakeholders: tourism operators, pensions and other accommodation facilities owners, info centers, equipment rental 
centers, tourist objectives administrators, local producers, craftsmen, local NGOs, mayors, local councils, other public institutions in charge with forest management, protected areas administration, public health and food safety, cultural sites and locals in general.

After four years of steadily increasing activity, the four persons team of Transylvanian Highlands managed to develop a network meeting ecotourism criteria (pensions, producers, crafts) and a tourism infrastructure by identifying and marking new tourist routes. Their network doubled during these 4 years and the destinations they promote became well-known outside the region.

Local traditions represent the backbone of all promotion activities, with an emphasis on architecture, gastronomy and also local customs, stories and traditional events.

The organization integrates all kinds of information, like tourist infrastructure in the area, producing leaflets with useful preventive advices (for carriages, for example), tourism statistics and area monitoring, promoting tourist destinations and events and creating various ecotourism packages.

They also are actively involved in raising awareness regarding ecotourism and cultural tourism opportunities for the local administration bodies and carry on regular educational activities for the local schools.

\section{Educational farms - The Artistic Farm from Poland}

The Artistic Farm is an agritourism, ecological and educational farm located in picturesque forest surroundings in the Malopolskie Voivodeship, in the south of Poland. There are many walking trails in the area, allowing to connect with nature and admire its beauty.

The owner, Maria Karas, together with her husband, have run this eco-agritourism farm since 18 years. The farm is certified as organic. It counts over 3 ha, including mainly meadows for the flock of 10 sheep whose wool is used during educational workshops, while the sheep themselves constitute an attraction for the visitors. Tourists can also admire the herbarium of local plant species, both arable and wild.

28 years ago, the owner started a regional band, Porebianie, often performing at events promoting the commune. The events such as dozynki (harvest home festival), local and national festivities are also a good chance to offer the farm's produce, and, consequently, promote local cuisine. The wide spectrum of the farm's activity allows for additional income, while pursuing the passion and hobby of the owner herself. The farm's agricultural production - in this case, ecological - is mainly herbs, which allows maintaining the farm's development despite of small acreage ( $3 \mathrm{ha}$ ) and engaging in non-agricultural activity, directly linked with primary agricultural production.

8 years ago the owners joined the Malopolska Herbal Village network, which was the first innovative product in the Malopolskie Voivodeship in terms of creating a network 
of farms. Currently, the network includes 20 herbal farms. Apart from herbs, Maria Karas also practices handicrafts, adding herbs to tissue paper bouquets and decoupage. The owners also use herbs to produce soaps, creams, candles, wine based tinctures, as well as cosmetic oils of, among others, lavender, calendula and thyme.

When it comes to agritourism, the farm offers 4 guestrooms with board. The meals are usually made using local herbs.

The farm's produce is made for guests and for the purpose of educational workshops, as well as for sale during local events, shows and fairs. The farm is also a member of the National Network of Educational Farms and the owner organises educational workshops. The educational packages are offered to both children and adults, as well as handicaped people; briefly, they are adjusted to a particular group of visitors. Tourists can chose one of the four themes: 1. Familiar with herbs; 2. Artistic combinations - paper flower making; 3. Traditional methods of cabbage fermentation; 4. From sheep to wool.

The farm perfectly fits into the concept of multi-functional development of rural areas, because apart from its basic agricultural, ecological activity, it also develops additional non-agricultural offer such as handicrafts, agritourism and educational activities, being a local innovation.

\section{Network tourist products - The Herbal Valley from Poland}

Barbara Zych owns a multi-functional farm of 5.7 ha, called the Herbal Valley. It is located in the Malopolskie Voivodeship, in the south of Poland.

The farm features traditional orchards of 70 years of age, and ponies used for agritourism, introduced in 2008. The owner offers agritourism packages created with the help of the Bialy Dunajec Local Action Group and the Agricultural Advisory Centre in Krakow, as innovative activity in terms of rural tourism.

The farm is situated in the Roznow-Ciezkowice region. The guests are offered 3 bedrooms, a bathroom, well equipped kitchen and living room with 8 additional places to sleep. All meals are prepared by the owner, specializing in regional cuisine.

The farm is innovative and multi-functional because all these activities merge into one coherent whole: agritourism, tourist packages, cooking classes and possibility to shop at the Local Product Centre. It is also possible to buy the produce online, as a single command or in a subscription mode through the platform http:/www.paczkaodrolnika. pl (Eng. Package from the farmer).

The farm is involved in agricultural production (fruit, vegetables, herbs, pulses) meeting the needs of the owner, as well as her guests. Apart from that, agritourism activities are offered. Barbara Zych offers 6 network tourist packages, each for a group of 6-7 people. Because the topics are specialised, such as herbal remedies, the packages are related with traditional and local products, for instance, Fasola Piekny Jas. The packages are offered to both adults and children, and they last from a couple of hours to a few days. 
Since a dozen or so years, tourists are not searching for accommodation alone, which is why the, so called, packages are offered. Currently, tourism is the main source of income for Barbara Zych.

The owner also belongs to the Association being a part of the Local Product Centre, organising a variety of courses, e.g. cooking classes for tourists. The Centre was established in December 2015, and, currently, Barbara Zych is its Vice President. It belongs to the group odrolnika established in 2011 and dealing with direct sales of organic produce from the farmer to the consumer.

The farm fits into the concept of multi-functional development of rural areas, because apart from agricultural activity, it is also engaged in agritourism. What is more, it is innovative thanks to the introduction of network packages of rural tourism.

It should be stressed that the farm's agricultural activity is directly linked with the project paczkaodrolnika (online direct sales) and the activities undertaken in the Local Product Centre.

\section{Conclusions}

Rural entrepreneurship is perceived as one of the most important elements of the local labour market, which encompasses the entire local community, not only people working in agriculture.

In both Poland and Romania, areas with rich environmental and cultural landscape have specialised in rural tourism. As shown in the above case studies, currently, rural tourism is characterised by multi-functionality combined directly with innovative activities.

Tourist offer, provided by both individual farmers and networks of farms, stands out with the hosts' professional attitude towards their work and, as a result, high quality of tourist services.

To conclude, it should be emphasised that the assumption of the described product innovations, as well as the presented case studies, is to make use of both the agricultural potential of the given area and the landscape, natural and cultural values, while promoting the concept of multi-functional development and ecological attitude.

\section{Conflict of interests}

The authors declare no conflict of interest. 


\section{References}

1. Bogusz M, Kmita-Dziasek E. (2015). Educational farms as an example of innovative entrepreneurship in rural areas. Innovation in rural tourism and new employment opportunities in rural areas. Ed. Kaminska W., Committee for Spatial Economy and Regional Planning, Polish Academy of Sciences, 163. Warsaw [in Polish Zagrody edukacyjne jako przyklad innowacyjnej przedsiebiorczości na obszarach wiejskich. Innowacyjnosc w turystyce wiejskiej a nowe mozliwosci zatrudnienia na obszarach wiejskich]

2. Durkalić., D. (2015). Vrnjacka Banja as a tourist brand or tourist region. In R. Borowiecki et al. (Eds.). Challenges of Contemporary Economies in the Face of Global Market Conditions. Book I. Cracow University of Economics, Cracow, May 25-27, Poland, pp.229-239. https://cfm.uek.krakow.pl/page/books-2

3. Idziak W. (2008). To reinvent the village. Thematic villages. Rural Development Foundation, Koszalin. [in Polish Wymyślic wies od nowa. Wioski tematyczne.]

4. Idziak W. (2005). Thematic villages. Use of information technology in the development of rural communities. Ed. Szczepanski P. Rural Development Foundation. Warsaw. [in Polish Wsie tematyczne. Wykorzystanie technologii informatycznych w rozwoju spolecznosci wiejskiej]

5. Idziak M., Idziak W. (2015). Innovative potential of thematisation in rural tourism and of rural development. Innovation in rural tourism and new employment opportunities in rural areas. Ed. Kaminska W. Committee for Spatial Economy and Regional Planning, Polish Academy of Sciences. 163. Warrsaw. [in Polish Potencjal innowacyjny tematyzacji w turystyce wiejskiej i rozwoju wsi. Innowacyjność w turystyce wiejskiej a nowe możliwości zatrudnienia na obszarach wiejskich]

6. Kachniewska M. (2015). Model of creating a network tourist product. Masovian Regional Tourism Organization. Warsaw. [in Polish Model tworzenia sieciowego produktu turystycznego.]

7. Kielian K. (2015). Educational farms in the promotion of local products. European Agricultural Fund for Rural Areas Develoment: Europe investing in rural areas. Krakow. [in Polish Zagrody edukacyjne w promocji produktow lokalnych. Europejski Fundusz Rolny na Rozwoju Obszarów Wiejskich: Europa inwestujaca w obszary wiejskie.]

8. Kmita-Dziasek E. (2015). Introduction to educational issues in the farm. European Agricultural Fund for Rural Areas Develoment: Europe investing in rural areas. Kraków. [in Polish Wprowadzenie do zagadnien edukacji w gospodarstwie rolnym. Europejski Fundusz Rolny na Rozwoju Obszarow Wiejskich: Europa inwestujaca w obszary wiejskie.]

9. Krzyzanowska K. (2013). Innovation in rural tourism. Innovations in the tourism development. Ed. Nuszkiewicz K., Roman M. Wydawnictwo Zespolu Szkol Centrum Ksztatcenia Rolniczego im. Jadwigi Dziubinskiej in Goladkowo. Goladkowo. [in Polish Innowacyjnosc w turystyce wiejskiej - teoria i praktyka. Innowacje w rozwoju turystyki.] 
10. Mackowiak M., Seelieb P. (2009). Thematic villages as a form of activation of tourism in rural areas. Tourist functions of rural areas. Ed. Sikorska-Wolak I. SGGW Publishing. Warsaw. [in Polish Wioski tematyczne jako forma aktywizacji turystycznej obszarów wiejskich. Turystyczne funkcji obszarow wiejskich.]

11. Majewski J. (2015). Innovation in rural tourist products. Innovation in rural tourism and new employment opportunities in rural areas. Ed. Kaminska W. Committee for Spatial Economy and Regional Planning, Polish Academy of Sciences, 163. Warsaw. [in Polish Innowacyjnosc wiejskich produktów turystycznych. Innowacyjnosc w turystyce wiejskiej a nowe możliwości zatrudnienia na obszarach wiejskich.]

12. Niculae M., Avram S., Vânău G., Pătroescu M. (2017). Effectiveness of Natura 2000 network in Romanian Alpine Biogeographical Region: an assessment based on forest landscape connectivity. Annals of Forest Research DOI:10.15287/ afr. 2016.793

13. Panasiuk A. (2014). Innovative processes in shaping the structure of tourist market. Enterprise in tourism, Ed. Snarski S.J., Jalinik M. EcoPress Publishing. Bialystok. [in Polish Procesy innowacyjne w ksztaltowaniu struktury rynku turystycznego. Przedsiebiorczosc w turystyce.]

14. Sieczko A. (2011). Masovian local products as the potential of the construction of a network mark product of rural tourism. Folia Pomeranae Universitatis Technologiae Stetinensis. Oeconomica 288 (64). Szczecin. [in Polish Mazowieckie produkty lokalne jako potencjal budowy sieciowego produktu markowego turystyki wiejskiej.]

15. Woźniczko M., Orłowski D. (2012). Innovation of wine routes in the tourist offer of selected European countries. The market of tourist services. Ed. Jalinik M., Ziółkowski R. Oficyna Wydawnicza Politechniki Bialostockiej. Bialystok. [in Polish Innowacyjnosc szlakow winnych w ofercie turystycznej wybranych krajow europejskich. Rynek uslug turystycznych.]

16. Vinohradnik K., Bogusz M. (2011). Introduction to the building of the network of rural tourism products, against general trends in national and international tourism, taking into consideration new phenomena in rural tourism. Building a network product of rural tourism. Rural Development Programme 2007-2013 support for the development of tourism in rural areas. Agricultural Advisory Centre in Brwinow/branch in Krakow. Krakow. [in Polish Wprowadzenie do zagadnienia budowy sieciowych produktow turystyki wiejskiej, na tle ogolnych tendencji w turystyce krajowej i miedzynarodowej z uwzglednieniem nowych zjawisk w turystyce na wsi. Budowa sieciowego produktu turystyki wiejskiej. Wsparcie PROW 2007-2013 dla rozwoju turystyki na obszarach wiejskich.] 